\title{
Nutritive value of tropical tree leaf meals in adult sows
}

\author{
P. Leterme ${ }^{1, \dagger}$, M. Botero ${ }^{1}$, A. M. Londoño ${ }^{1}$, J. Bindelle $^{2}$ and A. Buldgen ${ }^{2}$ \\ ${ }^{1}$ Universidad Nacional de Colombia, sede Palmira, Carrera 32, Palmira (Valle), Colombia \\ ${ }^{2}$ Faculté Universitaire des Sciences Agronomiques, B-5030 Gembloux, Belgium
}

${ }^{\dagger}$ Corresponding author present address: Prairie Swine Centre, 2105 - 8th Street East, Saskatoon, Saskatchewan, S7H 5N9, Canada. E-mail: pascal.leterme@usask.ca

\begin{abstract}
Tree leaf meals (TLM) are increasingly used in the tropics to feed pigs. The nutritive value of the TLM of cocoyam (Xanthosoma saggitifolium), mulberry (Morus alba) and Trichanthera gigantea, their effect on the digestive tract and their fermentation rate in the large intestine, were determined in adult sows given diets containing 150 or $300 \mathrm{~g}$ TLM per $\mathrm{kg}$. The TLM contained from 8.5 to $12.0 \mathrm{MJ}$ digestible energy per $\mathrm{kg}$ dry matter (DM) and from 60 to $125 \mathrm{~g}$ digestible protein per $\mathrm{kg} D M$. The digestibility was not affected $(\mathrm{P}>0.05)$ by their rate of incorporation in the diet. The apparent ileal protein digestibility of the diets containing $300 \mathrm{~g} \mathrm{TLM} \mathrm{per} \mathrm{kg}$ was also determined by the slaughtering method. It reached $80 \%$ for the basal diet and 54, 70 and 74\% for the Trichanthera-, mulberry- and cocoyam-based diets, respectively. No diet effect $(\mathrm{P}>0.05)$ was observed on the weight and length of the gastro-intestinal tract, with the exception of a heavier caecum in sows given the Trichanthera-based diet $(\mathrm{P}<0.01)$. The $\mathrm{pH}$ of the gastric fluid of these sows was also higher $(\mathrm{P}<0.001)$. The fermentation of the dietary fibre in the large intestine was evaluated by the gas technique using syringes. The cocoyam leaves presented the highest amount of total gas produced after fibre fermentation ( $\mathrm{P}<0.001)$. The ranking order of gas production was identical to that observed for the digestibility coefficients: Trichanthera $<$ mulberry $<$ cocoyam. In conclusion, TLM can represent up to 0.3 of a diet for sows. Their use in sow nutrition may be considered in tropical regions where protein sources are scarce.
\end{abstract}

Keywords: digestibility, nutritive value, pigs, tree leaf meal, tropical forage.

\section{Introduction}

In the tropics, pig production is accepted as long as these animals do not compete with humans for food. Due to the expanding human population, there is a urgent need to use more unconventional foods in livestock production. However, little information is available on the value of these resources and on how to produce and use them in sustainable production systems.

Protein is the most limiting dietary factor for tropical pig production (Ocampo et al., 2005; Leterme et al., 2005a and b). The animals are given by-products and low-protein crops such as cassava or banana and smallholders cannot afford the production of protein-rich crops such as soya bean or sunflower. In countries like Colombia, they are also limited by environmental conditions, since part of the land is dominated by mountainous topography.

Agroforestry seems to be a promising approach to combine production and environmental rehabilitation (Buck et al., 1999; Leakey, 1999). Indigenous trees are integrated in the farming systems and provide, at the same time, valuable products (fruits, leaves, wood) and environmental services (erosion control, water conservation, nutrient recycling).
Different unconventional tropical fruits are excellent sources of nutrients for the pig (Leterme et al., 2005a). Some browse trees and tuber plants also provide leaves with low content in antinutritional factors and high content in digestible nutrients. These leaves can be used in monogastric animal nutrition (Ly et al., 1998; Phuc et al., 2000; Dung et al., 2002). Their nutritional value and the production systems based on their use have been scarcely studied so far. In a previous study (Leterme et al., 2005b), we determined the composition and nutritive value of the leaves of three species used by smallholders of the Andes to feed their pigs. Two are browse trees: the mulberry (Morus alba L.) and Trichanthera gigantea $(\mathrm{H}$ and $\mathrm{B})$ Nees. They are widely used in animal nutrition. The third one is cocoyam (Xanthosoma saggitifolium Schott), a giant herb with big leaves $(>80 \mathrm{~cm})$ and a very large tuber. The latter, but not the leaves, is used in human nutrition. The leaves of these species are rich in protein and minerals.

Tree leaf meals (TLM) should be used primarily to feed sows because they better digest and transform raw foodstuffs and forages than smaller pigs (Le Goff and Noblet, 2001). A better knowledge of their use by sows would allow the development of production systems based on the 
agroforestry concept, as long as the rate of incorporation of TLM in the sow's diet is high enough to justify an investment in their production. Namely, it is necessary to confirm that sows are able to take advantage of raw ingredients with high fibre content.

The present work was conducted to determine the nutritional value of TLM in sows and to test the hypotheses that: (1) sows can tolerate diets containing up to $300 \mathrm{~g}$ TLM per $\mathrm{kg}$, and (2) a significant part of the non-starch polysaccharides (NSP) is fermented in the large intestine and may contribute to the supply in energy to the animal.

\section{Material and methods}

Total tract digestibility

Animals. Six sows of Colombian commercial breed, with an initial body weight ranging from 152 to $180 \mathrm{~kg}$ (mean 166 (s.e. 10) kg), were used for the study. After an adaptation period of 2 weeks to the diet, they were placed in metabolism cages designed to collect urine and faeces separately.

Diets. The tree foliage was hand-collected at an age of 3 to 4 months after the previous cutting. All the pieces of wood were removed. The cocoyam is a large plant $(>2 \mathrm{~m})$ with leaves measuring up to $80 \mathrm{~cm}$ (for further details, see Leterme et al. (2005b)). The stem $(>1.5 \mathrm{~m})$ was removed and only the leaf was kept. All the leaves were sun-dried on large plastic bags for 1 day (2 to 3 days for cocoyam) and ground by means of a hammer-mill, through a 3-mm mesh screen. Seven diets were formulated: a basal diet and six TLM-based diets. The basal diet was mainly composed of ground maize and soya-bean meal and supplemented with rice hulls and minerals (Table 1). The other six diets contained either 850 or $700 \mathrm{~g}$ of the basal diet per kg dry matter (DM) and, respectively, 150 or $300 \mathrm{~g}$ of sun-dried and ground (3-mm mesh screen) leaf meal of either Trichanthera, mulberry or cocoyam. Their chemical composition is detailed in Table 1.

Methodology. The digestibility of the basal diet was first determined on all the sows. They received $80 \mathrm{~g}$ DM per $\mathrm{kg}$ $\mathrm{M}^{0.75}$ per day, in two meals $(08: 00$ to $05: 00 \mathrm{~h})$, mixed with an equal amount of fresh water. After an adaptation period of 3 weeks, the faeces were totally collected for 8 days, weighed and an aliquot representing proportionately 0.05 of the excretion was composed and kept at $-15^{\circ} \mathrm{C}$. The refusals were collected $1 \mathrm{~h}$ after the meal, weighed and dried at $105^{\circ} \mathrm{C}$ for $24 \mathrm{~h}$ in order to determine the exact DM intake. The animals had permanent access to fresh water. The sows were then randomly allocated to one of the six TLM-based diets, according to a $6 \times 6$ Latin-square design. Treatments were assigned at random, within rows (sows) and columns (periods). After an adaptation period of 3 weeks, the faeces were collected as described above. The sows were assigned another diet at random but a same sow did not receive the same diet twice. The operation was repeated until each diet had been tested on all the sows. Between each period, the adaptation period to the diet was limited to 8 days. The basal diet was not included in the Latin square to reduce the length of the adaptation period between two treatments.

Analyses, calculations and statistics. The diets and the refusals were dried in an oven $\left(60^{\circ} \mathrm{C}\right)$. The faeces were freeze-dried. The diet ingredients, the refusals and the faeces were analysed for $\mathrm{DM}\left(105^{\circ} \mathrm{C}\right.$ for $\left.24 \mathrm{~h}\right)$, ash $\left(550^{\circ} \mathrm{C}\right.$ for $6 \mathrm{~h}$ ), nitrogen ( $\mathrm{N}$; Kjeldahl method), ether extract (Soxhlet method using petroleum ether), neutral- and aciddetergent fibre (NDF and ADF) and acid-detergent lignin

Table 1 Chemical composition (g/kg dry matter (DM)) and gross energy content of the tree leaf meals (TLM) and the experimental diets ${ }^{\dagger}$

\begin{tabular}{|c|c|c|c|c|c|c|c|c|c|c|}
\hline & \multicolumn{3}{|c|}{ Leaves } & \multicolumn{7}{|c|}{ Diets } \\
\hline & Trichanthera & mulberry & cocoyam & Basal & Tri150 & Mul150 & Coco150 & Tri300 & Mul300 & Coco300 \\
\hline \multicolumn{11}{|l|}{ Composition } \\
\hline Maize & & & & 700 & 595 & 595 & 595 & 490 & 490 & 490 \\
\hline Soya-bean meal & & & & 180 & 153 & 153 & 153 & 126 & 126 & 126 \\
\hline Rice hulls & & & & 60 & 51 & 51 & 51 & 42 & 42 & 42 \\
\hline Pre-mix ${ }^{\ddagger}$ & & & & 60 & 51 & 51 & 51 & 42 & 42 & 42 \\
\hline TLM $^{\S}$ & & & & - & 150 & 150 & 150 & 300 & 300 & 300 \\
\hline \multicolumn{11}{|l|}{ Analysis } \\
\hline DM $(\mathrm{g} / \mathrm{kg})$ & 152 & 271 & 124 & 920 & 930 & 924 & 917 & 923 & 927 & 922 \\
\hline Ash & 163 & 128 & 128 & 73 & 86 & 81 & 78 & 100 & 89 & 84 \\
\hline $\mathrm{CP}$ & 201 & 197 & 209 & 157 & 163 & 163 & 164 & 170 & 169 & 172 \\
\hline EE & 58 & 64 & 88 & 27 & 32 & 33 & 36 & 38 & 38 & 45 \\
\hline NDF & 468 & 350 & 310 & 171 & 217 & 198 & 190 & 263 & 225 & 211 \\
\hline ADF & 245 & 174 & 168 & 61 & 89 & 78 & 75 & 117 & 96 & 93 \\
\hline$A D L$ & 83 & 42 & 98 & 16 & 26 & 19 & 19 & 24 & 18 & 17 \\
\hline GE & $15 \cdot 84$ & 17.54 & $17 \cdot 30$ & $17 \cdot 34$ & $17 \cdot 11$ & $17 \cdot 37$ & $17 \cdot 31$ & $16 \cdot 89$ & 17.40 & $17 \cdot 31$ \\
\hline
\end{tabular}

${ }^{\dagger}$ The name of the diets mentions the name of the TLM incorporated in the diet (Tri = Trichanthera, Mul. = mulberry, Coco = cocoyam) and the rate of incorporation (either 150 or $300 \mathrm{~g}$ TLM per kg diet). Abbreviations are: $\mathrm{DM}=$ dry matter; $\mathrm{CP}=$ crude protein; $\mathrm{EE}=$ ether extract; $\mathrm{NDF}=$ neutral-detergent fibre; $\mathrm{ADF}=$ acid-detergent fibre; $\mathrm{ADL}=$ acid-detergent lignin; $\mathrm{GE}=$ gross energy $(\mathrm{MJ} / \mathrm{kg} \mathrm{DM})$.

${ }^{\ddagger}$ The pre-mix contained (per kg): $430 \mathrm{~g} \mathrm{CaCO}_{3}, 250 \mathrm{~g} \mathrm{Ca} \mathrm{HPO}_{4}, 160 \mathrm{~g} \mathrm{NaCl}$ and $170 \mathrm{~g}$ of mineral and vitamin pre-mix (Nutribal, Palmira, Colombia). The latter supplied, per kg diet: $7.5 \mathrm{mg}$ retinol; $0.125 \mathrm{mg}$ cholecalciferol; $13 \mathrm{mg}$ alpha-tocophereol; 6 mg phytylmenaquinone; $10 \mathrm{mg}$ riboflavin; $35 \mathrm{mg}$ calcium pantothenate; $75 \mathrm{mg}$ niacin; $2.5 \mathrm{mg}$ pyridoxine; $0.05 \mathrm{mg}$ cyanocobalamin; $0.05 \mathrm{mg}$ biotin; $200 \mathrm{mg}$ choline; $150 \mathrm{mg} \mathrm{Mn}$; $500 \mathrm{mg} Z \mathrm{Zn} ; 40 \mathrm{mg} \mathrm{Cu}, 200 \mathrm{mg} \mathrm{Fe} ; 2 \mathrm{mg} \mathrm{l} ; 0.5 \mathrm{mg} \mathrm{Se}, 1 \mathrm{mg} \mathrm{Co}$

$\S$ The DM of the dry TLM ranged from 920 to $930 \mathrm{~g} / \mathrm{kg}$. 


\section{Nutritive value of tropical tree leaf meals in adult sows}

(ADL). NDF, ADF and ADL were analysed by the Van Soest method, using an ANKOM A200 - fibre analyser, with filter bags. A correction was made for the ash content of the residues after treatment. Amylase $(2 \mathrm{ml}$ termamyl, Novo Nordisk, Bagsvaerd, Denmark) was added to the NDF and ADF solutions for the basal diet but not for the forages. Gross energy was determined by means of a Parr 1340 calorimeter (Parr Instruments, Moline, USA).

The apparent digestibilities were calculated by difference between the amount of nutrients ingested and excreted. The digestibilities of the TLM alone were calculated from the digestibilities of the basal diet and those of the TLMbased diets.

The statistical comparison of the six TLM-based diets was performed by means of the GLM procedure of the Statistical Analysis Systems Institute (SAS, 1999), using the following model:

$$
Y_{i j k}=\alpha+A_{i}+P_{j}+D_{k}+S_{l}+L_{m}+\left(S_{l} \times L_{m}\right)+\varepsilon
$$

where $Y_{i j k}$ is the digestibility, $\alpha$ the general mean, $A_{i}$ the effect of the th animal, $P_{j}$ that of the $j$ th period, $D_{k}$ that of the $k$ th diet, $S$, that of the th forage species, $L_{m}$ that of the $m$ th levels of incorporation, $\left(S_{1} \times L_{m}\right)$ the interaction between the species and the level of incorporation and $\epsilon$ the residual error. The analysis was followed by a comparison of the digestibilities of the diets using the NewmanKeuls multiple range test. The basal diet was not included in the comparison, since its digestibility was determined apart from the Latin square.

Ileal digestibility and weight and length of organs

Animals. Sixteen sows of Colombian commercial breed, weighing from 190 to $240 \mathrm{~kg}(217 \pm 19 \mathrm{~kg})$, were used. They were kept in large crates $\left(4 \mathrm{~m}^{2}\right)$ during the whole study.

Diets. Four diets were formulated: a basal one (see experiment 1) and three diets containing $300 \mathrm{~g} / \mathrm{kg}$ TLM of either Trichanthera, mulberry or cocoyam and $700 \mathrm{~g} / \mathrm{kg}$ of the basal diet, as described above. All the diets were supplemented with chromium III oxide $\left(3 \mathrm{~g} \mathrm{Cr}_{2} \mathrm{O}_{3}\right.$ per $\mathrm{kg}$ $\mathrm{DM})$ as a marker. The experiments were conducted in agreement with the guidelines of the National University of Colombia for care and use of laboratory animals.

Methodology. The experimental scheme was a completely randomized design. The sows were randomly allocated to one of the experimental diets (four sows per diet). After 2 weeks of adaptation to the diet, the sows were killed by electric shock and their carotid vein was sectioned and followed by exsanguination. For practical organization, two sows were sacrificed every day and the experiment lasted 3 weeks. The abdomen was immediately opened using a surgical scalpel blade and the gastro-intestinal tract, starting from the end of the oesophagus to the rectum, was isolated. It was divided in segments: stomach, ileum (last $2 \mathrm{~m}$ ), caecum and colon. The content was collected, weighed, freeze-dried and kept at $-15^{\circ} \mathrm{C}$ until analysed. The emptied organs were measured and weighed.
Analyses, calculations and statistics. The contents of the ileum were analysed for their DM, N, NDF and gross energy (see experiment 1) and chromium contents. The latter was determined by colorimetry after nitro-perchloric hydrolysis, as described by Furukawa and Tsukahara (1966). Chromium was also analysed in the diet.

The apparent digestibility (D) of the diets was based on the chromium content of both diets and digesta and calculated as follows:

$$
\begin{aligned}
\mathrm{D}(\%)= & 100-\left[100 \times\left(\% \mathrm{M}_{\text {diet }} / \% \mathrm{M}_{\text {ileum }}\right)\right. \\
& \left.\times\left(\% \mathrm{~N}_{\text {ileum }} / \% \mathrm{~N}_{\text {diet }}\right)\right],
\end{aligned}
$$

where $\% \mathrm{M}$ is the concentration in marker and $\% \mathrm{~N}$ that in nutrients in the diets or in the ileal digesta.

Significant differences were determined by analysis of variance followed by comparisons using the Newman-Keuls multiple range test by means of the InStat statistical software (GraphPad, San Diego, CA).

\section{Fibre fermentation in the large intestine}

The rate and kinetics of fibre fermentation of the TLM and the diets in the large intestine, were studied in vitro using the gas production technique developed by Menke and Steingass (1988) for rumen fermentation studies and adapted to pigs by Boudry et al. (2004). The samples of diets and forages were first treated with pepsin, followed by pancreatin, in order to simulate the digestive processes in the stomach and in the small intestine, as described by Boisen and Fernandez (1997). The residues were then incubated in a solution containing faeces and buffer, for measurement of the rate of fibre fermentation (see below).

Pepsin-pancreatin hydrolysis. Briefly, the samples $(0.5 \mathrm{~g})$ were incubated for $2 \mathrm{~h}$ at $39^{\circ} \mathrm{C}$ in a buffer solution $(\mathrm{pH}$ 2.0) containing $25 \mathrm{mg}$ pepsin (2000 FIP-U per g; Merck 7190). The $\mathrm{pH}$ was then adjusted to 6.8 and $100 \mathrm{mg}$ pancreatin (Sigma P1750) added and a new incubation was run for $4 \mathrm{~h}$ at $39^{\circ} \mathrm{C}$. After the hydrolysis, the residues were filtered on a nylon cloth $(42 \mu \mathrm{m})$, washed with ethanol $(2 \times 10 \mathrm{ml} 95 \%$ ethanol $)$ and acetone $(2 \times 10 \mathrm{ml} 99 \%$ acetone $)$, dried, for $24 \mathrm{~h}$ at $60^{\circ} \mathrm{C}$, weighed and analysed for $\mathrm{N}$ content.

Gas production technique. Two hundred $\mathrm{mg}$ of substrate were placed in a $100 \mathrm{ml}$ Kolbenprober glass syringe filled with $30 \mathrm{ml}$ of an inoculum prepared from faeces of two sows given a diet composed of $700 \mathrm{~g}$ basal diet and $300 \mathrm{~g}$ of a mixture of the three TLM. The preparation of the inocula was made under permanent flow of $\mathrm{CO}_{2}$ to maintain anaerobic conditions. The inocula were prepared mixing the faeces of the two sows in equal parts. Faecal samples were collected in plastic bags saturated with $\mathrm{CO}_{2}$ and immediately placed in a water bath at $39 \pm 1{ }^{\circ} \mathrm{C}$. The buffer solution $(180 \mathrm{ml})$ used by Menke and Steingass (1988) was added to the bags. The mixture of the faecal sample with the buffer solution was subjected to mechanical pummelling with a Stomacher Lab Blender 400 (Seward Medica1, Norfolk, UK) for 60s to remove solid associated bacteria from the fibre and to 
suspend them in the liquid. The inocula were obtained by filtering the suspension through a $250-\mu \mathrm{m}$ mesh size screen and adding the rest of the buffer solution in order to reach the desired dilution of faeces in the buffer solution $(0.1 \mathrm{~g} / \mathrm{ml}$ buffer $)$. The gas-tests were performed transferring $30 \mathrm{ml}$ of inoculum in the syringes and placing them in an incubator at $39 \pm 0.5^{\circ} \mathrm{C}$. The volumes of gas production in the syringes were recorded after $2,5,8,12,16,20,24,48$, $72,96,120$ and $144 \mathrm{~h}$ of incubation. Five syringes were used for each substrate and three syringes, containing just inoculum, were used as blanks. All the syringes were put in the same water-bath and one inoculum was prepared for the whole study.

Calculations. The gas volume recorded during the fermentation of each syringe was calculated as follows:

$$
V^{c o r r}(t)=\frac{V(t)-V_{0}-B(t)^{*} V_{0}}{W}
$$

where $V(t)(\mathrm{ml} / \mathrm{g})$ is the gas accumulation to time $t(\mathrm{~h})$ corrected by the amount of incubated substrate and the production of the blanks, $V(t)(\mathrm{ml})$ the volume occupied by the inoculum and the gas at time $t, V_{O}(\mathrm{ml})$ the volume of inoculum in the syringe at the start of the fermentation, $B(t)$ ( $\mathrm{ml}$ gas per $\mathrm{ml}$ of inoculum) the mean gas production at time $t$ of the blanks per $\mathrm{ml}$ of inoculum and $W(\mathrm{~g})$ the amount of substrate placed in the syringe. Outlying observations, caused by accidental leakage of gas, were discarded.

Gas accumulation profiles were fitted to the model of France et al. (1993):

$$
\begin{aligned}
G & =0, & & \text { if } 0<t<L \\
& =G_{f}(1-\exp \{-\langle b(t-L)+c(\sqrt{t}-\sqrt{L})\rangle\}), & & \text { if } t \geq L
\end{aligned}
$$

where $G(\mathrm{ml} / \mathrm{g})$ represents the gas accumulation to time, $G_{f}$ $(\mathrm{ml} / \mathrm{g})$ the maximum gas volume for $t=\infty$ and $L(\mathrm{~h})$ the lag time before the fermentation starts. The constants $b$ (per h) and $c\left(\right.$ per $\left.\mathrm{h}^{1 / 2}\right)$ determine the fractional rate of degradation of the substrate $\mu$ (per h), which is postulated to vary with time as follows:

$$
\mu=b+\frac{c}{2 \sqrt{t}} \text {, if } t \geq L .
$$

The kinetics parameters $\left(G_{f}, L, \mu_{t=T / 2}\right.$ and $\left.T / 2\right)$ were compared in the statistical analysis. $T / 2$ is the time to half asymptote when $G=G_{f} / 2$. At this time, the rate of gas production is in a linear phase, near its maximum.

Statistical analyses of the kinetics parameters were performed by means of an analysis of variance and a classification of means by the Student-Newman-Keuls method using the GLM procedure of SAS (1999) with the following general linear model:

$$
Y=\alpha+D_{i}+T L M L_{j}+(D \times T L M L)_{i j}+\varepsilon
$$

where $Y$ is the result, $\alpha$ the mean, $D_{i}$ the effect of the tree specie of the diet $(i=1,2,3), T L M L_{j}$ the effect of the tree leaf meal level incorporation $(j=1,2)$ and $\epsilon$ the error term.

\section{Results}

The total tract digestibilities of the diets and the TLM are detailed in Table 2. No interaction between tree species and level of TLM in the diet was observed $(P>0.05)$, therefore, the results are presented per species and TLM level. The digestibilities of the TLM alone, calculated by difference, are also provided. The digestibilites of the Trichanthera - based diets were lower $(P<0.05)$ than those based on mulberry or cocoyam leaf meals. The same was observed for the digestibilities of the TLM alone. On the contrary, no difference $(P>0.05)$ was monitored between the mulberry and cocoyam leaf meals. The digestible energy (DE) content of the Trichanthera leaf meal was also lower $(P<0.05)$ than that of the other two species. The increase in TLM in the diet from 150 to $300 \mathrm{~g} / \mathrm{kg}$ led to a decrease $(P<0.05)$ in digestibility of the components of the TLM-based diets, with the exception of NDF. On the contrary, no level effect $(P>0.05)$ was observed for the digestibilities of the TLM alone. The NDF digestibility of the latter was not calculated because the high variability in NDF digestibility of the TLM diets led to aberrant values.

The ileal digestibilities of DM, N, energy and NDF of the diets are detailed in Table 3 . No difference $(P>0.05)$ was observed between the basal diet and the TLM-based diets for the digestibility of DM and NDF. The protein digestibility of the Trichanthera - based diet was lower $(P=0.003)$ than that of the other diets. The energy digestibility of the latter diet was lower $(P=0.009)$ than that of the basal diet but not $(P>0.05)$ than that of the other TLM-based diets. The order was the same as that observed at faecal level, with mulberry having intermediary values between Trichanthera (lowest) and cocoyam. The differences between the basal diet and the TLM-based diets were higher than those observed for the total tract digestibilities.

The length and weight of the organs were not affected by the diets $(P>0.05)$, with the exception of a heavier caecum $(P<0.001)$ in sows given the Trichanthera-based diet. The $\mathrm{pH}$ of the stomach content of these sows was also higher $(P=0.013)$

The kinetic parameters of fibre fermentation of the diets and the TLM are detailed in Table 4. The production of gas with time is illustrated in Figures 1 and 2 for the TLM and the diets, respectively. The TLM and the level of leaves in the diets affected $(P<0.01)$ all the parameters, with the exception of the lag time, which was not modified by the level of leaves $(P>0.05)$. Interactions were also observed between the species and between the TLM levels in the diet, for T $(P<0.01)$ and T/2 $(P<0.05)$. The total volume of gas produced after the TLM fermentation followed the same ranking order as that observed for the total tract and ileal digestibilities: Trichanthera $<$ mulberry $<$ cocoyam (Table 4). The leaves, as well as the diets, usually needed more than $30 \mathrm{~h}$ of fermentation before a plateau of gas production was reached (Figures 1 and 2). 
Nutritive value of tropical tree leaf meals in adult sows

Table 2 Apparent total tract digestibilities and digestible energy content of the tree leaf meal (TLM)-based diets and the TLMs alone ${ }^{t}$

\begin{tabular}{|c|c|c|c|c|c|}
\hline & \multicolumn{3}{|c|}{ Apparent digestibility (\%) } & \multirow[b]{2}{*}{ NDF } & \multirow[b]{2}{*}{ DE (MJ/kg DM) } \\
\hline & DM & $\mathrm{N}$ & Energy & & \\
\hline $\begin{array}{l}\text { Basal diet }^{\ddagger} \\
\text { TLM-based diets }\end{array}$ & $83.7(1.5)$ & $88.3(1.6)$ & $86 \cdot 1(0 \cdot 8)$ & $37 \cdot 2(4 \cdot 9)$ & $14.92(0.69)$ \\
\hline \multicolumn{6}{|l|}{$\begin{array}{l}\text { TLM-based diets } \\
\text { Species }\end{array}$} \\
\hline Trichanthera & $75 \cdot 4^{b}$ & $74 \cdot 3^{\mathrm{b}}$ & $77 \cdot 8^{\mathrm{b}}$ & $41 \cdot 0^{\mathrm{b}}$ & 13.23 \\
\hline Mulberry & $78 \cdot 8^{a}$ & $80 \cdot 0^{\mathrm{a}}$ & $81.0^{\mathrm{a}}$ & $49 \cdot 5^{\mathrm{a}}$ & 14.09 \\
\hline Cocoyam & $80 \cdot 2^{\mathrm{a}}$ & $81 \cdot 4^{\mathrm{a}}$ & $81.5^{\mathrm{a}}$ & $52 \cdot 4^{\mathrm{a}}$ & 13.58 \\
\hline \multicolumn{6}{|l|}{ Level (per kg) } \\
\hline $150 \mathrm{~g}$ TLM & $80 \cdot 0^{\mathrm{a}}$ & $80 \cdot 6^{\mathrm{a}}$ & $82 \cdot 2^{\mathrm{a}}$ & $46 \cdot 6$ & 13.85 \\
\hline $300 \mathrm{~g}$ TLM & $76 \cdot 3^{b}$ & $76 \cdot 6^{b}$ & $77.9^{\mathrm{b}}$ & 53.9 & 13.41 \\
\hline s.e. & $2 \cdot 1$ & $2 \cdot 8$ & $2 \cdot 0$ & $5 \cdot 0$ & 0.94 \\
\hline \multicolumn{6}{|l|}{ Source of variation ${ }^{\S}$} \\
\hline Species (S) & 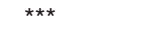 & 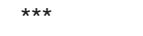 & $\star \star *$ & ** & \\
\hline Level (L) & *** & ** & $\star \star \star *$ & & \\
\hline \multicolumn{6}{|l|}{ TLM } \\
\hline \multicolumn{6}{|l|}{ Species effect } \\
\hline Trichanthera & $48 \cdot 6^{\mathrm{b}}$ & $29 \cdot 8^{\mathrm{b}}$ & $53.8^{\mathrm{b}}$ & - & $8.53^{\mathrm{b}}$ \\
\hline Mulberry & $63 \cdot 6^{\mathrm{a}}$ & $49 \cdot 3^{\mathrm{a}}$ & $65 \cdot 4^{\mathrm{a}}$ & - & $11.48^{\mathrm{a}}$ \\
\hline Cocoyam & $70 \cdot 6^{a}$ & $56 \cdot 6^{a}$ & $69 \cdot 3^{a}$ & - & $12 \cdot 00^{\mathrm{a}}$ \\
\hline \multicolumn{6}{|l|}{ Level effect } \\
\hline $150 \mathrm{~g}$ TLM & 61.6 & $42 \cdot 1$ & $63 \cdot 1$ & - & $10 \cdot 70$ \\
\hline $300 \mathrm{~g}$ TLM & $60 \cdot 3$ & $49 \cdot 4$ & $62 \cdot 6$ & - & $10 \cdot 63$ \\
\hline s.e. & 9.4 & $9 \cdot 7$ & $10 \cdot 4$ & - & 1.72 \\
\hline \multicolumn{6}{|l|}{ Source of variation $\S$} \\
\hline $\mathrm{S}$ & 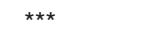 & *** & * & & ** \\
\hline $\mathrm{L}$ & & $\|$ & & & \\
\hline
\end{tabular}

\section{Discussion}

The results of faecal protein digestibility are in agreement with data obtained for other TLM (cassava, batata, Leucaena) in growing pigs (51 to 54\%, Ly et al., 1998; Phuc et al., 2000; An et al., 2004) but are markedly higher than those (12 to $36 \%$ ) obtained previously in smaller pigs (18 to $35 \mathrm{~kg}$ ) (Leterme et al., 2003 and 2005b). In piglets, the digestibility of the TLM decreased sharply when their rate of incorporation was increased from 0 to $200 \mathrm{~g} / \mathrm{kg}$ diet. In the present study, the digestibility of the TLM was not affected by the rate of incorporation, even at $300 \mathrm{~g}$ TLM per kg diet. The difference can be ascribed to the better capacity of large animals to ingest and digest high fibre diets (Leterme and Théwis, 2004; Noblet and Van Milgen, 2004).

Table 3 lleal digestibility of dry matter, nitrogen, energy and neutral-detergent fibre (NDF) of diets containing $300 \mathrm{~g}$ tree leaf meal per $\mathrm{kg}$, in sows. Weight and length of the digestive organs and $\mathrm{pH}$ of the organ contents

\begin{tabular}{|c|c|c|c|c|c|c|}
\hline & Basal diet & Trichanthera & Mulberry & Cocoyam & s.e. & Significance \\
\hline \multicolumn{7}{|l|}{ Ileal digestibility (\%) } \\
\hline Dry matter & 73.9 & $67 \cdot 1$ & $64 \cdot 2$ & 68.4 & 1.1 & \\
\hline Crude protein & $80 \cdot 3^{\mathrm{a}}$ & $60 \cdot 7^{b}$ & $69 \cdot 6^{a}$ & $73 \cdot 6^{\mathrm{a}}$ & $2 \cdot 3$ & ** \\
\hline Energy & $76 \cdot 0^{\mathrm{a}}$ & $60 \cdot 6^{\mathrm{b}}$ & $66 \cdot 7^{\mathrm{a}, \mathrm{b}}$ & $70 \cdot 7^{a, b}$ & 1.9 & ** \\
\hline NDF & $25 \cdot 7$ & 24.5 & 27.5 & $37 \cdot 2$ & $3 \cdot 3$ & \\
\hline \multicolumn{7}{|l|}{ Organs } \\
\hline \multicolumn{7}{|l|}{ Length (m) } \\
\hline Small intestine & $17 \cdot 4$ & 18.5 & $18 \cdot 7$ & $18 \cdot 7$ & $9 \cdot 0$ & \\
\hline Large intestine & $6 \cdot 2$ & $6 \cdot 4$ & 6.5 & $6 \cdot 7$ & $14 \cdot 2$ & \\
\hline \multicolumn{7}{|c|}{ Weight ( $\mathrm{g} / 100 \mathrm{~kg}$ live weight) } \\
\hline Stomach & 549 & 585 & 680 & 541 & 15 & \\
\hline Small intestine & 1169 & 1289 & 1269 & 1286 & 15 & \\
\hline Caecum & $97^{\mathrm{a}}$ & $160^{\mathrm{b}}$ & $124^{\mathrm{a}}$ & $112^{\mathrm{a}}$ & 15 & 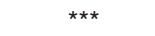 \\
\hline Colon & 1498 & 1873 & 1495 & 1570 & 29 & \\
\hline \multicolumn{7}{|l|}{$\mathrm{pH}$} \\
\hline Stomach & $2 \cdot 65^{\mathrm{a}}$ & $4 \cdot 30^{\mathrm{b}}$ & $2 \cdot 49^{\mathrm{a}}$ & $3 \cdot 27^{\mathrm{a}, \mathrm{b}}$ & 0.25 & * \\
\hline Colon & $6 \cdot 26$ & 6.57 & 6.45 & 6.75 & 0.07 & $t$ \\
\hline Caecum & $6 \cdot 24^{a}$ & $6.59^{\mathrm{b}}$ & $6 \cdot 41^{a, b}$ & $6 \cdot 50^{a, b}$ & 0.04 & \\
\hline
\end{tabular}

${ }^{a, b}$ Means with different superscripts in the same row differ significantly $(P<0.001)$.

${ }^{\dagger}$ Approaching significance $(P<0 \cdot 1)$. 
Leterme, Botero, Londoño, Bindelle and Buldgen

Table 4 Kinetic parameters, fitted according to the France model, of the gas accumulation curves obtained after fermentation with faecal inoculum of tree leaf meals (TLM) and TLM-based diets that were previously pre-digested with pepsin-pancreatin

\begin{tabular}{|c|c|c|c|c|}
\hline Substrate & Lag time (h) & Half-time to asymptote (h) & Fractional rate of degradation (per h) & Maximum gas volume $(\mathrm{ml} / \mathrm{g})$ \\
\hline \multicolumn{5}{|l|}{ TLM } \\
\hline Trichanthera & $0.4^{\mathrm{a}}$ & $17 \cdot 2^{a}$ & 0.03 & $288^{a}$ \\
\hline Mulberry & $1 \cdot 2^{\mathrm{a}, \mathrm{b}}$ & $12 \cdot 5^{\mathrm{b}}$ & 0.04 & $312^{\mathrm{a}}$ \\
\hline Cocoyam & $1.7^{\mathrm{b}}$ & $11 \cdot 2^{\mathrm{b}}$ & 0.05 & $380^{\mathrm{b}}$ \\
\hline s.e. & 0.4 & $1 \cdot 2$ & 0.01 & 13 \\
\hline Significance & ** & $\star \star \star *$ & & $* * \star$ \\
\hline \multicolumn{5}{|l|}{ Diets } \\
\hline Basal diet & $0.5^{\mathrm{a}}$ & $12 \cdot 2^{\mathrm{a}}$ & $0.04^{a}$ & $321^{a}$ \\
\hline Trichanthera-150 & $0.6^{\mathrm{a}}$ & $7 \cdot 5^{\mathrm{b}}$ & $0.09^{b}$ & $164^{\mathrm{b}}$ \\
\hline Mulberry-150 & $0.6^{\mathrm{a}}$ & $12 \cdot 5^{a}$ & $0.04^{a}$ & $331^{a}$ \\
\hline Cocoyam-150 & $1 \cdot 3^{b}$ & $8 \cdot 4^{\mathrm{b}}$ & $0.07^{a, b}$ & $276^{a}$ \\
\hline Trichanthera-300 & $0.9^{a, b}$ & $9 \cdot 9^{\mathrm{a}, \mathrm{b}}$ & $0.06^{a, b}$ & $215^{\mathrm{b}}$ \\
\hline Mulberry-300 & $0.7^{\mathrm{a}}$ & $11.9^{\mathrm{a}}$ & $0.04^{a}$ & $397^{\mathrm{C}}$ \\
\hline Cocoyam-300 & $1 \cdot 2^{b}$ & $13 \cdot 0^{a}$ & $0.04^{a}$ & $413^{C}$ \\
\hline s.e. & 0.4 & $1 \cdot 0$ & 0.01 & 27 \\
\hline Significance & * & $\star \star *$ & $\star \star \star *$ & $\star \star * *$ \\
\hline \multicolumn{5}{|l|}{ Source of variation ${ }^{\dagger}$} \\
\hline Diet & & *** & $\star \star * *$ & $* * *$ \\
\hline TLM level & & $\star * *$ & $\star \star$ & $\star \star *$ \\
\hline Diet $\times$ TLM level & ** & * & $\ddagger$ & \\
\hline
\end{tabular}

a,b,c Means with different superscripts in a same column differ significantly $(P<0.05)$.

${ }^{\dagger}$ Basal diet is not included is this analysis.

${ }^{\ddagger}$ Approaching significance $(P<0 \cdot 1)$.

The weight of the gastro-intestinal tract of growing pigs increases when they are given high fibre diets (Anugwa et al., 1989). No such effect was observed in the present study (Table 3), with the exception of an enlarged caecum in sows given Trichanthera leaves. This could be explained by a lower NDF digestibility of the latter, combined to a higher fibre content, that resulted in a higher NDF flow to the caecum. The results thus confirm our first hypothesis that sows are adapted to use high fibre diet and can be given with diets containing up to $300 \mathrm{~g}$ TLM per $\mathrm{kg}$.

The overall digestibility of the Trichanthera leaves was lower than that of the other species (Tables 2 and 3). The lower value is ascribable to their higher fibre content. Trichanthera was also found to be the species with the highest N-NDF content (59\% of the total N) among 28 species of shrub species (Shayo and Udén, 1999). Part of the protein remains entrapped in the cell walls.

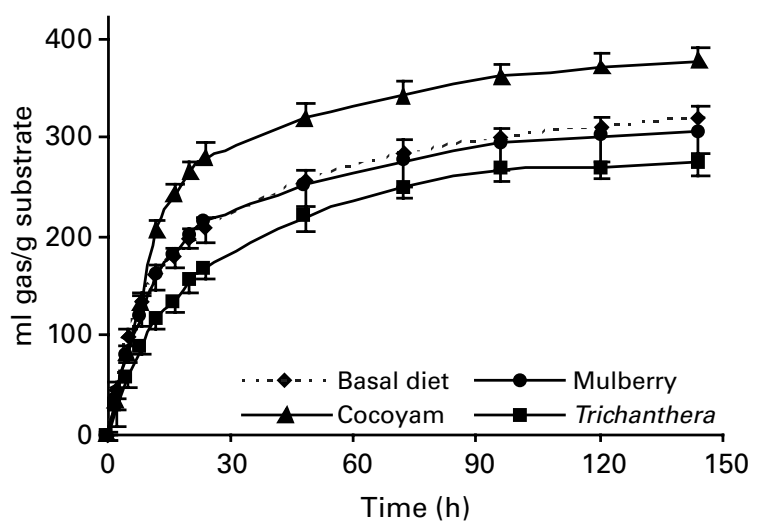

Figure 1 Gas accumulation over time after incubation of tree leaf meals and the basal diet with faecal inoculum.
The lower protein digestibility of the Trichanthera leaves could also be related to the higher $\mathrm{pH}$ observed for the gastric fluid of the sows given this diet (Table 3). The high $\mathrm{pH}$ (4.3), measured $16 \mathrm{~h}$ after the last meal, is higher than the optimal $\mathrm{pH}$ required for a maximal pepsin activity $(\mathrm{pH} 2)$. It may be related to the high mineral content of the Trichanthera leaves. The latter contain up to $60 \mathrm{~g} \mathrm{Ca}$ per $\mathrm{kg}$ DM v. 20 to $30 \mathrm{~g}$ for mulberry and cocoyam (Leterme et al., 2006). Sixteen hours after the last meal, the stomach still contained $60 \%$ of the DM of the last meal (data not shown). The long delay may have favoured the release of $\mathrm{Ca}$ in the fluid and a change in $\mathrm{pH}$.

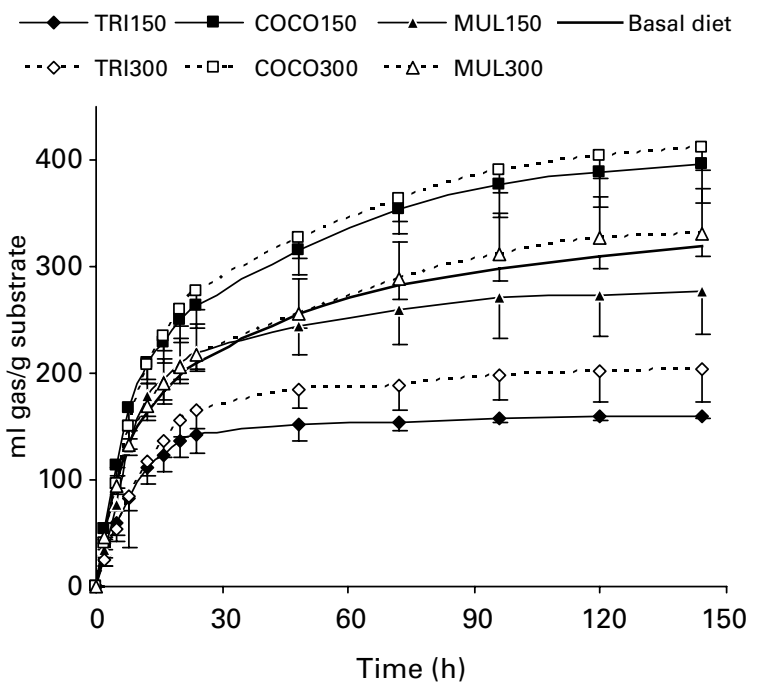

Figure 2 Gas accumulation over time after incubation of tree leaf meal-based diets and the basal diet with faecal inoculum. Diet codes are given in Table 1. 
Our second hypothesis was that part of the digestibility of the leaves could be ascribed to the fermentation of the leaf NSP in the pig large intestine. In reality, more than a quarter of the total NDF content had already disappeared in the small intestine. Other authors report similar values: $25 \%$ of the NDF of sweet potato leaves (An et al., 2004) and $23 \%$ of the NDF of Leucaena leaf meal-based diets (Ly et al., 1998).

However, the validity of the conventional methods of fibre analysis (NDF, crude fibre) to analyse intestinal contents has been questioned (Cummings and Englyst, 1987), namely because the soluble fraction is not considered with these techniques. In the present case, the soluble fibre content of the tree leaves was expected to be low but could not be estimated. On the other hand, Ly et al. (1998) reported a high increase in short-chain fatty acids (SCFA) concentration in the ileum of pigs receiving TLM and demonstrated the presence of an active microbial population in the upper part of the gastrointestinal tract. Thus, as stated by our observation and those of Ly et al. (1998) and An et al. (2004), it is highly probable that the fermentation of the NSP in the small intestine was high.

The values of total tract NDF digestibility were higher (Table 2) than those related by other laboratories: from 31 to $44 \%$ for diets containing from 200 to $400 \mathrm{~g}$ TLM per $\mathrm{kg}$ diet (Ly et al., 1998; Phuc et al., 2000; An et al., 2004). The ranking order was similar to that observed for total tract digestibility, i.e. Trichanthera $<$ mulberry $<$ cocoyam (Table 2). The same was also observed for the results of gas production obtained with the in vitro technique, for the TLM alone as well as for the TLM-based diets (Figures 1 and 2).

The in vitro fermentation was obtained after treatment of the food samples in a solution of pepsin and then pancreatin, thus eliminating the soluble fraction. The gas production reflects the fermentation of the insoluble fraction only. The higher gas production obtained for the diets containing $300 \mathrm{~g}$ TLM per $\mathrm{kg}$ compared with those containing $150 \mathrm{~g}$ can be explained by the fact that the incubated residues contained higher amounts of TLM fibre. Since the amount of matter incubated in the syringe was the same for both samples, it can be concluded that the fermentation of the carbohydrates of the TLM was higher than that of the carbohydrates of the basal diet.

The data confirm that the fibre of the TLM is partially fermentable in the large intestine and that the fermentation probably contributes to energy supply in the pig. Van Wieren (2000) estimated that pigs fed with roughages can receive up to $26 \%$ of their energy in the form of SCFA coming from the fermentation of the roughages. The DE content of the TLM ranged from 8.53 to $12.00 \mathrm{MJ} / \mathrm{kg} \mathrm{DM}$ (or 2040 to $2870 \mathrm{kcal} / \mathrm{kg} \mathrm{DM})$. The value is very good for mulberry and cocoyam, if we consider that cereals, for example, contain about 14.6 MJ DE per kg DM). However, DE overestimates the net energy content of ingredients high in fibre and protein, as in TLM (Noblet and Van Milgen, 2004). In cereals, for example, the net energy corresponds more or less to $74 \%$ of the DE, whereas in lucerne, which has a composition comparable with that of the TLM, it represents only $50 \%$ (Sauvant et al., 2002). The digestible energy of lucerne reaches $7.94 \mathrm{MJ} / \mathrm{kg}$ and the net energy $3.93 \mathrm{MJ}$, which is low, compared with the net energy value of barley, for example ( $9.70 \mathrm{MJ}$ in sows). Thus, the energy content of the TLM is not as attractive as the present DE values may suggest.

In conclusion, the intake of up to $300 \mathrm{~g}$ TLM per $\mathrm{kg}$ DM intake does not affect the digestive processes in sows. They can provide from 8.53 to $12.00 \mathrm{MJ}$ DE per $\mathrm{kg} \mathrm{DM}$ and from 60 to $125 \mathrm{~g}$ digestible protein per $\mathrm{kg} \mathrm{DM}$. Further work is required to develop sustainable pig production systems based on TLM and confirm the nutritive potential of the latter.

\section{Acknowledgements}

The authors gratefully acknowledge the expert technical assistance of the personnel of the National University of Colombia and the Faculty of Agricultural Sciences of Gembloux. The project was financed by the Belgian Co-operation (CIUF, Brussels, CERCRI project,) and the International Atomic Energy Agency (IAEA, Vienna, Austria; reference COL/5/020)

\section{References}

An, L. V., Thu Hong, T. T. and Lindberg, J. E. 2004. lleal and total tract digestibility in growing pigs fed cassava root meal diets with inclusion of fresh, dry and ensiled sweet potato (Ipomea batatas L.) leaves. Animal Feed Science and Technology 114: 127-139.

Anugwa, F., Varel, V., Dickson, J., Pond, W. and Krook, L. 1989. Effects of dietary fiber and protein concentration on growth, feed efficiency, visceral organ weights and large intestine microbial populations of swine. Journal of Nutrition 119: 879-886.

Boisen, S. and Fernandez, J. 1997. Prediction of the total tract digestibility of energy in feedstuffs and pig diets by in vitro analyses. Animal Feed Science and Technology 68: 277-286.

Boudry, C., Buldgen, A., Anciaux, B., Ruiz Peña, M. and Leterme, P. 2004. Mise au point d'une méthode de détermination in vitro du taux de fermentation des fibres dans le gros intestin du porc. Journées de la Recherche Porcine en France 36: 219-225.

Buck, L., Lassoie, J. and Fernandes, E. 1999. Agroforestry in sustainable agricultural systems. CRC Press, Boca Raton, FL.

Cummings, J. and Englyst, H. 1987. Fermentation in the human large intestine and the available substrates. American Journal of Clinical Nutrition 45: 1243-1255.

Dung, X. N., Manh, L. and Udén, P. 2002. Tropical fibre sources for pigs: digestibility, digesta retention and estimation of fibre digestibility in vitro. Animal Feed Science and Technology 102: 109-124.

France, J., Dhanoa, M. S., Theodorou, M. K., Lister, S. J., Davies, D. R. and Isac, D. 1993. A model to interpret gas accumulation profiles associated with in vitro degradation of ruminant feeds. Journal of Theoretical Biology 163: 99-111.

Furukawa, A. and Tsukahara, H. 1966. On the acid digestion method for the determination of chromic oxide as an index substance in the study of digestibilibity of fish fed. Bulletin of the Japanese Society of Scientific Fisheries 32: 502-506.

Leakey, R. 1999. Potential for novel food products from agroforestry trees: a review. Food Chemistry 66: 1-14.

Le Goff, G. and Noblet, J. 2001. Comparative digestibility of dietary energy and nutrients in growing pigs and adult sows. Journal of Animal Science 79: 2418-2427.

Leterme, P., Buldgen, A., Estrada, F. and Londoño, A. 2006. Mineral content of tropical fruits and unconventional foods of the Andes and the rain forest of Colombia. Food Chemistry 95: 644-652.

Leterme, P., Garcia, M., Londoño, A., Rojas, M., Buldgen, A. and Souffrant, W. 2005a. Chemical composition and nutritional value of pejibaye (Bactris gasipaes Kunth) in rats. Journal of the Science of Food and Agriculture 85: 1505-1512. 


\section{Leterme, Botero, Londoño, Bindelle and Buldgen}

Leterme, P., Londoño, A., Estrada, F., Souffrant, W. and Buldgen, A. 2005b. Chemical composition, nutritive value and voluntary intake of tropical tree foliage and cocoyam in pigs. Journal of the Science of Food and Agriculture 85: 1725-1732.

Leterme, P., Rosales, A., Valencia, A., Mera, R., Souffrant, W., Londoño, A., Sarria, P. and Buldgen, A. 2003. Effect of intake of tree foliage and aquatic plant on the rate of ingestion and fecal and ileal digestibilities in pigs. In Proceedings of the ninth international symposium on the digestive physiology of the pig, University of Alberta, Edmonton, pp. 370-372

Leterme, P. and Théwis, A. 2004. Effect of pig bodyweight on ileal amino acid endogenous losses after ingestion of a protein-free diet enriched in pea inner fibre isolates. Reproduction, Nutrition, Development 44: 407-417.

Ly, J., Reyes, J., Macias, M., Martinez, V., Domínguez, P. and Ruiz, R. 1998. Ileal and total tract digestibility of leucaena meal in growing pigs. Animal Feed Science and Technology 70: 265-273.

Menke, K. H. and Steingass, H. 1988. Estimation of the energetic feed valued obtained from chemical analysis and in vitro gas production using rumen fluid. Animal Research and Development 28: 7-55.

Noblet, J. and Van Milgen, J. 2004. Energy value of pig feeds: effect of pig body weight and energy evaluation system. Journal of Animal Science 82: 229-238.
Ocampo, L., Leterme, P. and Buldgen, A. 2005. A survey of pig production systems in the rain forest of the Pacific coast of Colombia. Tropical Animal Health and Production 37: 315-326.

Phuc, B., Ogle, B. and Lindberg, J. 2000. Effect of replacing soybean protein with cassava leaf protein in cassava root meal based diets for growing pigs on digestibility and $\mathrm{N}$ retention. Animal Feed Science and Technology 83: 223235.

Sauvant, D., Perez, J. -M. and Tran, G. 2002. Tables de composition et de valeur nutritive des matières premières destinées aux animaux d'élevage. INRA Publications, Versailles.

Shayo, C. and Udén, P. 1999. Nutritional uniformity of crude protein fractions in some tropical browse plants estimated by two in vitro methods. Animal Feed Science and Technology 78: 141-151.

Statistical Analysis Systems Institute. 1999. User's guide: statistics version 8.0. SAS Inc., Cary, NC.

Van Wieren, S. 2000. Digestibility and voluntary intake of roughages by wild boar and Meishan pigs. Animal Science 71: 149-156.

(Received 18 April 2005-Accepted 23 November 2005) 